\section{Implementation of The Policy of The Minister of Health of The Republic of Indonesia Concerning The Health Protocol For The Community In Place And Public Facilities To Press The Spread of Covid-19 In The Sidoarjo Area}

\author{
Implementasi Kebijakan Menteri Kesehatan Republik Indonesia \\ Tentang Protokol Kesehatan Bagi Masyarakat Di Tempat Dan Fasilitas \\ Umum Untuk Menekan Penyebaran Covid-19 Di Wilayah Sidoarjo
}

Hendra Sukmana

Universitas Muhammadiyah Sidoarjo

\begin{abstract}
The number of positive COVID-19 patients in the Sidoarjo area continues to increase. As of April 19, 2020, there were 11,028 positive COVID-19 patients, 6,068 suspect patients, 617 patients who were declared dead due to Covid-19 and 10,398 people declared cured of Covid-19. This study was conducted to identify and describe the implementation of policies in the form of the Decree of the Minister of Health of the Republic of Indonesia Number HK. 01.07/Menkes/382/2020 concerning Protocols for Public Health in Public Places and Facilities in the Context of Prevention and Control of Corona Virus Disease 2019 (Covid-19) in the Sidoarjo area. Data analysis was carried out by Miles and Huberman interactive analysis. The results showed that the implementation of the Decree of the Minister of Health of the Republic of Indonesia Number HK. 01.07/Menkes/382/2020 concerning Protocols for Public Health in Public Places and Facilities in the Context of Prevention and Control of Corona Virus Disease 2019 (Covid-19) in the Sidoarjo region can be seen from four things. First, communication, where policy communication is carried out through socialization and education related to $3 \mathrm{M}$ (wearing masks, maintaining distance and washing hands) to the people of Sidoarjo. However, in practice, socialization and education related to $3 \mathrm{M}$ (wearing masks, maintaining distance and washing hands) are considered insufficient to overcome the Covid-19 pandemic. Need to add 2M (limit mobility and stay away from crowds) so that it becomes $5 \mathrm{M}$. This is because mobility and crowd problems are felt to have contributed to causing many Covid-19 virus infections. Second, resources, where the task of fixing the level of compliance with health protocols actually requires the help of many parties. Not only from themselves, the media is also tasked with providing a sense of security and positive messages to the community. Likewise, the government should also not instill too much fear, but rather recommendations that arouse the desire to comply with health protocols.
\end{abstract}


Third, the disposition which shows that the government has implemented a policy on Large-Scale Social Restrictions by closing schools and workplaces, closing tourist attractions and entertainment venues, restricting religious activities and public facilities. Likewise, offices have been urged to make rules for their employees to work from home. Fourth, the bureaucratic structure in which several parties in this case are the Sidoarjo district government and its ranks and related parties to carry out supervision. This is because supervision of the implementation of health protocols during the Covid-19 pandemic is important.

Keywords: Implementation, Health Protocol, Covid-19

\section{PENDAHULUAN}

Sudah setahun pandemi Covid-19 melanda wilayah Indonesia. Covid-19 atau yang sering disebut dengan virus corona adalah virus berbahaya dengan ukuran sangat kecil. Covid-19 juga dianggap sebagai penyakit yang menyebabkan sindrom pernafasan akut parah akibat terinveksi virus SARS-CoV-2. Dampak dari terinveksinya virus tersebut adalah dapat menginfeksikan sel-sel epitel pada saluran pernafasan yang memiliki parameter efek dari ringan hingga mematikan. Gejala utama dari Covid-19 adalah tubuh menjadi demam, mengalami batuk dan nafas pendek, di mana gejala tersebut dapat muncul antara 2 sampai 14 hari setelah infeksi. Banyaknya pemberitaan tentang Covid-19 yang berasal dari Kota Wuhan di Negera Cina dikarenakan virus tersebut telah menyebabkan ratusan ribu nyawa meninggal dunia (Masrul et al., 2020).

Di Indonesia sendiri, mewabahnya Covid-19 diumumkan pada awal Maret 2020. Data terakhir menunjukkan bahwa sampai 18 April 2021, jumlah kasus Covid-19 di Indonesia menembus angka 1.604.348 kasus. Hal tersebut dikarenakan terdapat penambahan pasien positif sebanyak 4.585 dibandingkan hari sebelumnya. Pada sisi lain, juga terdapat penambahan pasien sembuh sebanyak 4.873 orang. Selain itu, terdapat pasien meninggal dunia yang juga bertambah 96 orang. Secara keseluruhan total kasus kematian akibat Covid19 di Indonesia berjumlah 43.424 orang dan per 18 April 2021 kasus aktif Covid-19 di Indonesia berjumlah 105.859 pasien yang dirawat di rumah sakit atau menjalani isolasi mandiri (Sinuhaji, 2021). Berikut statistik kasus Covid-19 di Indonesia per 18 April 2021:

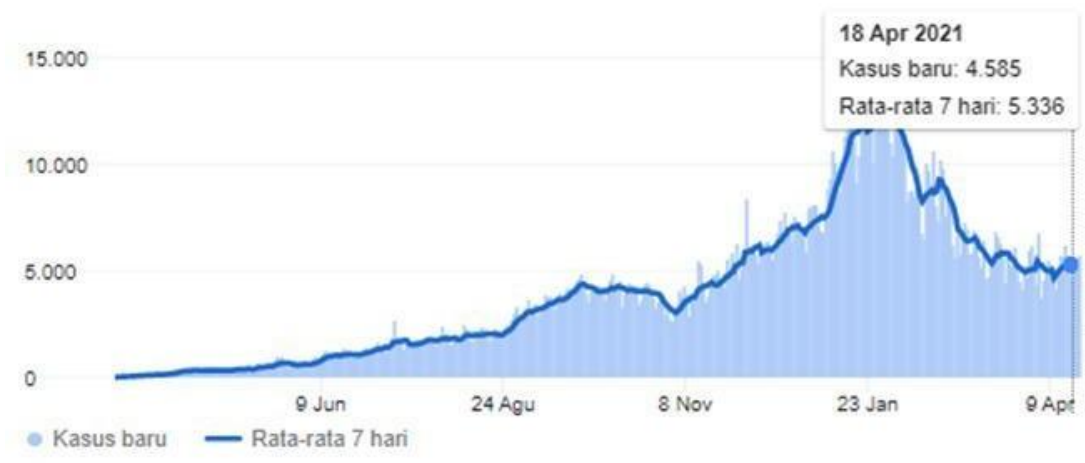

Gambar 1 Statistik Kasus Covid-19 di Indonesia

Sumber: Center for Systems Science and Engneering (CSSE) di Johns Hopkins University, 2021 
Berbagai upaya terus dilakukan oleh pemerintah baik di lingkup Provinsi maupun Kabupaten Daerah di seluruh Indonesia untuk memutus mata rantai penyebaran virus Covid19, salah satunya adalah di wilayah Jawa Timur. Pemerintah Provinsi Jawa Timur secara resmi meluncurkan Peraturan Gubernur Jawa Timur Nomor 53 Tahun 2020 tentang Penerapan Protokol Kesehatan dalam Pencegahan dan Pengendalian Corona Virus Disease 2019. Gubernur Jawa Timur meminta seluruh warga di seluruh Provinsi Jawa Timur untuk mematuhi regulasi protokol kesehatan yang berlaku untuk melindungi diri sendiri, keluarga dan orang lain dari penyebaran Covid-19 yang berbahaya.

Pada praktiknya, dilakukan operasi yustisi sebagai bagian dari penegakan hukum dari berbagai regulasi yang diterbitkan baik pemerintah pusat, provinsi maupun kabupaten/kota. Tujuannya adalah untuk mengajak masyarakat untuk saling melindungi satu sama lain dan gotong royong untuk melawan Covid-19 melalui kepatuhan pada protokol kesehatan. Adanya operasi yustisi dianggap sebagai penguat dalam penegakan protokol kesehatan yang lebih tegas dan masif. Namun, pantauan di lapangan menunjukkan bahwa masih banyak masyarakat yang belum memiliki kesadaran untuk dapat mematuhi protokol kesehatan Covid-19 seperti menggunakan masker, mencuci tangan dan menjaga jarak. Masyarakat belum sepenuhnya mendukung pemerintah dalam memutus mata rantai virus Covid-19. Masih banyak ditemui masyarakat yang berkerumun, duduk berdekatan, tidak menggunakan masker dan makan di tempat umum

Temuan awal menunjukkan bahwa kesadaran masyarakat Sidoarjo pada kepatuhan protokol kesehatan kian menurun. Selain itu, saat diberlakukan pembatasan kegiatan masyarakat (PPKM), masih banyak ditemui masyarakat yang kurang disiplin menerapkan protokol kesehatan. Beberapa masyarakat terlihat berkerumun di beberapa lokasi, jarang ada masyarakat yang mencuci tangan serta tidak menggunakan masker saat melakukan aktivitas di luar rumah. Beberapa masyarakat mengaku bahwa pihaknya lupa untuk menggunakan masker, bahkan ada yang mengaku ketinggalan dan jatuh di jalan.

Kurang patuhnya masyarakat pada protokol kesehatan di wilayah Sidoarjo membuat angka pasien positif Covid-19 mengalami peningkatan. Berikut data tentang sebaran pasien positif Covid-19 di Sidoarjo.

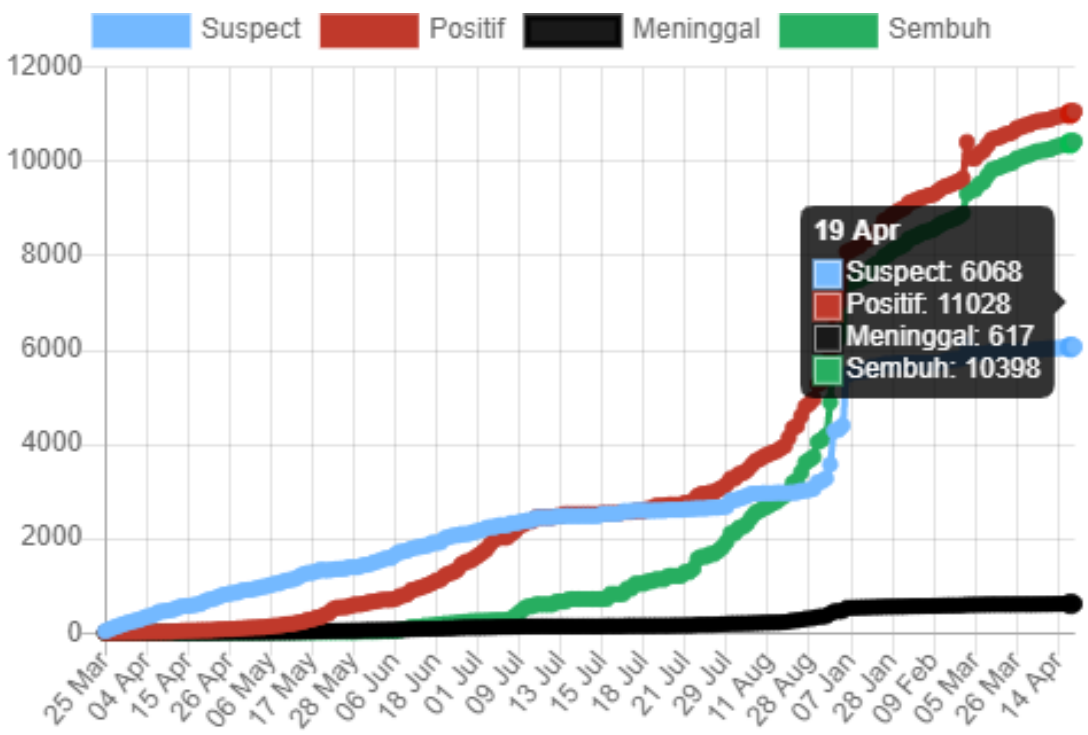

Gambar 1.2 Grafik Perkembangan Covid-19 di Kabupaten Sidoarjo Sumber: covid19.sidoarjokab.go.id 


\section{METODE PENELITIAN}

Pendekatan yang digunakan dalam penelitian ini adalah pendekatan kualitatif. Tipe penelitian ini adalah studi kasus.Peran peneliti dalam peneliti adalah sebagai instrumen atau human instrument.Penelitian ini menggunakan teknik pengumpulan data berupa wawancara, observasi dan dokumentasi. Teknik analisis data yang digunakan dalam penelitian ini adalah model interaktif dari Miles dan Huberman, yang terdiri dari reduksi data, penyajian data serta penarikan kesimpulan dan verifikasi (Miles \& Huberman, 2014).

Untuk menguji keabsahan data, digunakan teknik triangulasi yaitu teknik pemeriksaan keabsahan data yang memanfaatkan sesuatu yang lain di luar data untuk keperluan pengecekan atau perbandingan data. Triangulasi yang digunakan dalam penelitian ini adalah triangulasi sumber. Triangulasi sumber dilakukan dengan cara membandingkan data dari sumber yang berbeda dengan teknik wawancara untuk menggali informan, kemudian hasil dari data tersebut diuji kebenarannya dengan cara membandingkan (Waseso \& Hidayat, 2016).

\section{HASIL DAN PEMBAHASAN}

Kebijakan (policy) umumnya dipahami sebagai keputusan yang diambil untuk menangani hal-hal tertentu (Hamdi, 2014). Namun, kebijakan bukanlah sekedar keputusan yang ditetapkan, kebijakan (policy) lebih sebagai suatu rangkaian panjang dari kegiatan-kegiatan yang berkaitan dan akibatnya bagi mereka yang berkepentingan, daripada hanya sekedar suatu keputusan. Selanjutnya, (Anggara, 2014) mendefinisikan bahwa kebijakan publik adalah segala sesuatu yang dikerjakan atau tidak dikerjakan oleh pemerintah, alasan suatu kebijakan harus dilakukan dan manfaat bagi kehidupan bersama harus menjadi pertimbangan yang holistik agar kebijakan tersebut mengandung manfaat yang besar bagi warganya dan tidak menimbulkan kerugian, di sinilah pemerintah harus bijaksana dalam menerapkan suatu kebijakan. (Hamdi, 2014) menyebutkan bahwa tahap-tahap kebijakan publik terdiri dari lima tahap yaitu: penentuan agenda (agenda setting), perumusan alternatif kebijakan (policy formulation), penetapan kebijakan (policy legitimation), pelaksanaan kebijakan (policy implementation), dan penilaian kebijakan (policy evaluation).

Salah satu tahapan kebijakan adalah implementasi kebijakan. Implementasi kebijakan dianggap sebagai aspek terpenting dari keseluruhan proses kebijakan. Implementasi kebijakan adalah wujud nyata dari suatu kebijakan karena pada tahapan implementasi, suatu kebijakan tidak hanya terbatas pada perwujudan secara riil dari kebijakan melainkan memiliki keterkaitan dengan konsepsi atau dampak yang akan mengarah pada pelaksanaan kebijakan yang dijalankan. Menurut (Solichin, 2012) implementasi kebijakan sebagai negara sebagai suatu organisasi publik selain mempunyai tujuan (goals) yang harus direalisasikan, ia juga mempunyai berbagai permasalahan yang harus diatasi, dikurangi atau dicegah.

Keputusan Menteri Kesehatan Republik Indonesia Nomor HK. 01.07/Menkes/382/2020 tentang Protokol Kesehatan Bagi Masyarakat di Tempat dan Fasilitas Umum dalam Rangka Pencegahan dan Pengendalian Corona Virus Disease 2019 (Covid-19) menunjukkan bahwa ruang lingkup protokol kesehatan meliputi upaya pencegahan dan pengendalian Covid-19 di tempat dan fasilitas umum dengan memperhatikan aspek perlindungan kesehatan individu dan titik-titik kritis dalam perlindungan kesehatan masyarakat, yang melibatkan pengelola, penyelenggara, atau penanggung jawab tempat dan fasilitas umum serta masyarakat pengguna.Pemerintah Indonesia menerapkan langkah social distancing dan penerapan protokol kesehatan seperti menggunakan masker, mencuci tangan atau menggunakan hand sanitizer, menjaga jarak atau menghindari kerumunan, meningkatkan daya tahan tubuh, mengkonsumsi gizi seimbang serta menerapkan perilaku hidup bersih dan sehat. Selain itu, diterapkan etika batuk dan bersin bagi masyarakat yaitu dengan menutup mulut dan hidup 
menggunakan lengan atas bagian dalam. Hal tersebut dilakukan untuk mengurangi paparan virus ke orang lain.

George C. Edward III, menunjukkan bahwa terdapat empat variabel yang mempengaruhi kinerja implementasi, yaitu: komunikasi, sumber daya, disposisi dan struktur birokrasi. Berikut empat variabel George C. Edward III berkaitan dengan implementasi Keputusan Menteri Kesehatan Republik Indonesia Nomor HK. 01.07/Menkes/382/2020 tentang Protokol Kesehatan Bagi Masyarakat di Tempat dan Fasilitas Umum dalam Rangka Pencegahan dan Pengendalian Corona Virus Disease 2019 (Covid-19) di wilayah Sidoarjo:

1. Komunikasi

Komunikasi adalah proses penyampaian informasi dari komunikator kepada komunikan. Sementara itu, komunikasi kebijakan adalah proses penyampaian dari pembuat kebijakan kepada pelaksana kebijakan, yang kemudian disesuaikan dengan target kebijakan tersebut. Terkait dengan implementasi Keputusan Menteri Kesehatan Republik Indonesia Nomor HK. 01.07/Menkes/382/2020 tentang Protokol Kesehatan Bagi Masyarakat di Tempat dan Fasilitas Umum dalam Rangka Pencegahan dan Pengendalian Corona Virus Disease 2019 (Covid-19) di wilayah Sidoarjo, hasil penelitian menunjukkan bahwa komunikasi kebijakan dilakukan dengan sosialisasi dan edukasi terkait 3M (memakai masker, menjaga jarak dan mencuci tangan) kepada masyarakat Sidoarjo. Namun pada praktiknya, sosialisasi dan edukasi terkait 3M (memakai masker, menjaga jarak dan mencuci tangan) dianggap tidak cukup untuk mentatasi pandemi Covid-19. Perlu ditambahkan 2M (membatasi mobilitas dan menjauhi kerumunan) sehingga menjadi 5M. Hal tersebut dikarenakan masalah mobilitas dan kerumunan sangat terasa memberikan kontribusi untuk menyebabkan banyak infeksi virus Covid-19.

Edukasi terkait dengan penerapan protokol kesehatan memang diperlukan untuk pencegahan dan pengurangan tingkat penularan virus Covid-19. Pada Keputusan Menteri Kesehatan Republik Indonesia Nomor Hk.01.07/Menkes/328/2020 terdapat beberapa poin sederhana namun penting untuk diketahui dan diaplikasikan yaitu: mencuci tangan dengan baik baik dan benar, menghindari penggunaan alat pribadi (alat makan, alat sholat dan lainlain), serta menjaga kebersihan diri dan lingkungan. Ketiga hal tersebut merupakan komponen yang harus ditekankan pada materi edukasi terkait ilustrai rutinitas saat diberlakukan new normal. Perlu untuk dijelaskan tentang bagaimana cara mencuci tangan dengan baik. hal ini dapat dilakukan dengan merujuk panduan yang diberikan oleh WHO, di mana saat mencuci tangan individu disarankan untuk menggunakan sabun dan air yang mengalir. Dengan mencuci tangan dengan baik dan efektif maka virus yang mungkin menempel di tangan akan hilang dan mengurangi individu terpapar virus Covid-19.

Melihat perkembangan sebaran orang-orang yang terinfeksi Covid-19 di wilayah Sidoarjo, pembatasan mobilitas orang perlu diambil oleh pemerintah untuk melindungi kesehatan publik. Paling tidak pemerintah dapat membatasi mobilitas orang antar pulau dan membatasi orang berkumpul atau berkerumum dalam jumlah besar di satu tempat. Dengan demikian, pemerintah akan punya ruang untuk menata zona-zona pelayanan kesehatan dan memaksimalkan penggunaan sumber daya menjadi lebih baik sekaligus melokalisasi wilayah penyebaran. Di samping itu, pemerintah harus segera menjalankan kewajibannya melindungi hak atas pelayanan kesehatan. Ada beberapa prinsip yang perlu diacu. Pertama, perlu adanya ketersediaan layanan kesehatan yang mencukupi bagi penduduk secara keseluruhan. Kedua, layanan kesehatan tersebut harus bisa dijangkau oleh penduduk, baik dari sisi biaya maupun lokasi. Ketiga, layanan kesehatan tersebut harus sesuai dengan standar yang ada. Keempat, layanan kesehatan tersebut harus bisa diakses secara setara oleh setiap orang, dengan perhatian khusus kepada kelompok paling rentan. 
Kebijakan pengendalian mobilitas masyarakat menjadi sangat penting untuk memutus mata rantai penularan Covid-19. Kebijakan ini juga betujuan untuk mencegah lonjakan pasien Covid-19 baik dengan gejala berat dan ringan maupun tanpa gejala atau OTG agar rumah sakit dan tempat khusus isolasi mandiri yang disediakan pemerintah pusat dan daerah masih memiliki daya tampung yang cukup.

Pada sisi lain, setiap orang bisa menjadi carrier virus corona dan tidak diketahui tanda secara fisik bila tanpa gejala. Karena karakter virus seperti itu, pemerintah membagikan tips untuk mencegah penularan Covid-19 salah satunya dengan menghindari penularan. Langkah yang bisa dilakukan untuk mencegah penularan Covid-19 adalah hindari kerumunan karena dalam kerumunan tersebut tidak diketahui siapa yang tertular Covid-19, apalagi tanpa gejala.Dengan menghindari kerumunan, seseorang dianggap melindungi orang rentan seperti lansia dan orang dengan penyakit kronis karena jika orang rentan tersebut tertular virus corona akan berakibat fatal. Selain itu, menghindari kerumunan harus diiringi dengan jaga jarak dengan orang lain, memakai masker jika keluar rumah, dan rajin mencuci tangan pakai sabun.Apabila masyarakat tidak menghindari kerumunan, maka pihaknya akan berkomunikasi dengan kondisi fisik yang berdekatan sehingga berisiko sangat tinggi pada penyebaran dan penularan virus Covid-19. Sebab, virus Covid-19 dapat menular melalui droplet atau percikan-percikan ludah yang berpindah dari orang yang sakit ke orang yang sehat. Percikan ludah sangat mungkin berpindah dari satu orang ke orang lain, ketika seseorang berbicara, batuk atau bersin.

Secara garis besar, $5 \mathrm{M}$ tersebut berlaku untuk semua kalangan, Meskipun vaksin Covid-19 sudah mulai diedarkan, gerakan 5M Covid-19 harus tetap dilaksanakan. Hal ini dilakukan tidak lain agar pandemi bisa segera usai dan kehidupan bisa kembali normal. Sosialisasi dan edukasi untuk pencegahan penyebaran Covid-19 masih tetap dilakukan dengan tidak hanya melakukan 3M, tetapi 5M. Guna mendisiplinkan masyarakat yang beraktivitas di luar rumah, dilakukan operasi yustisi pada masyarakat yang tidak mematuhi protokol kesehatan dalam berkendara karena tidak menggunakan masker dan pada masayarakat yang dengan sengaja mendatangi kerumunan.

\section{Sumber Daya}

Sumber daya merupakan faktor yang turut mempengaruhi dalam implementasi. Sumber daya dalam penelitian ini adalah input yang digunakan agar oprogram dapat terlaksana dengan baik yaitu berupa staff, informasi, wewenang dan fasilitas. Oleh karena itu, setiap sumber daya harus terukur dan terencana secara detail. Hal ini dikarenakan seakurat-akuranya sebuah komunikasi serta ketentuan yang jelas tidak akan dapat maksimal apabila tidak memiliki sumber daya yang memadai untuk melakukan dan mendukung kebijakan tersebut secara efektif.

Tugas untuk membenahi tingkat kepatuhan terhadap protokol kesehatan sebenarnya dibutuhkan bantuan banyak pihak. Tak hanya dari diri sendiri, media juga bertugas untuk memberikan rasa aman dan pesan positif kepada masyarakat. Begitu juga pemerintah, sebaiknya juga tidak terlalu menanamkan ketakutan melainkan anjuran yang membangkitkan keinginan mematuhi protokol kesehatan. Diperlukan upaya untuk membangun mindset dan kebiasaan positif seperti 3M (mencuci tangan, menjaga jarak dan memakai masker). 


\section{Disposisi}

Disposisi adalah watak dan karakteristik implementator yang memiliki sikap atau perspektif yang berbeda dengan pembuat kebijakan. Pemerintah telah menerapkan kebijakan tentang Pembatasan Sosial Berskala Besar dengan meliburkan sekolah dan tempat kerja, penutupan obyek-obyek wisata dan tempat hiburan, pembatasan kegiatan keagamaan serta fasilitas umum. Begitu juga kantor-kantor telah dihimbau untuk membuat aturan agar pegawainya bekerja di rumah. Namun di sisi lain, masih banyak perusahaan dan pelaku bisnis mengalami kesulitan untuk menerapkan aturan ini, sehingga para pegawai masih wajib masuk kantor atau bekerja di tempat usahanya. Sebagai akibatnya mobilitas dan kegiatan masyarakat yang bekerja di luar rumah masih berjalan seperti biasa. Hal ini berdampak terhadap tujuan diterapkannya pembatasan sosial menjadi kurang efektif dan cenderung melemahkan upaya pemutusan mata rantai penyebaran Covid-19.

\section{Struktur Birokrasi}

Struktur birokrasi apabila dianalisis dengan seksama merupakan kebijakan dengan struktur birokrasi yang telah terfragmentasi. Fragmentasi adalah penyebaran tanggungjawab suatu kebijakan kepada beberapa badan sehingga diperlukan suatu koordinasi.

Beberapa pihak khususnya pembuat kebijakan juga harus melakukan koordinasi dengan beberapa pihak dalam hal ini adalah pemerintah kabupaten Sidoarjo beserta jajaran dan pihak terkait untuk melakukan pengawasan. Hal ini dikarenakan pengawasan terhadap penerapan protokol kesehatan selama pandemi Covid-19 menjadi hal penting. Perlu dilakukan pengawasan yang ketat terkait dengan penerapan protokol kesehatan terutama $3 \mathrm{M}$ (memakai masker, mencuci tangan dan menjaga jarak). Selain itu, dapat dilakukan kampanye penyuluhan tentang protokol kesehatan $3 \mathrm{M}$ yaitu memakai masker, rajin mencuci tangan dan selalu menjaga jarak. Hal ini perlu dilakukan secara terus menerus agar masyarakat tidak lupa bahwa penyebaran Covid-19 banyak datang dari pergerakan manusia. Terkait demikian pelaksanaan 3M harus dijalankan secara ketat. Selain itu, dilakukan kerjasama dengan pihak terkait dalam hal ini adalah pemerintah daerah dan dinas kesehatan dalam melakukan pengawasan penerapan protokol kesehatan. 


\section{KESIMPULAN}

Keputusan Menteri Kesehatan Republik Indonesia Nomor HK. 01.07/Menkes/382/2020 tentang Protokol Kesehatan Bagi Masyarakat di Tempat dan Fasilitas Umum dalam Rangka Pencegahan dan Pengendalian Corona Virus Disease 2019 (Covid-19) di wilayah Sidoarjo dapat dilihat dari empat hal. Pertama, komunikasi, di mana komunikasi kebijakan dilakukan dengan sosialisasi dan edukasi terkait 3M (memakai masker, menjaga jarak dan mencuci tangan) kepada masyarakat Sidoarjo. Namun pada praktiknya, sosialisasi dan edukasi terkait 3M (memakai masker, menjaga jarak dan mencuci tangan) dianggap tidak cukup untuk mentatasi pandemi Covid-19. Perlu ditambahkan 2M (membatasi mobilitas dan menjauhi kerumunan) sehingga menjadi 5M. Hal tersebut dikarenakan masalah mobilitas dan kerumunan sangat terasa memberikan kontribusi untuk menyebabkan banyak infeksi virus Covid-19. Kedua, sumber daya, di mana tugas untuk membenahi tingkat kepatuhan terhadap protokol kesehatan sebenarnya dibutuhkan bantuan banyak pihak. Tak hanya dari diri sendiri, media juga bertugas untuk memberikan rasa aman dan pesan positif kepada masyarakat. Begitu juga pemerintah, sebaiknya juga tidak terlalu menanamkan ketakutan melainkan anjuran yang membangkitkan keinginan mematuhi protokol kesehatan. Ketiga, disposisi yang menunjukkan bahwa pemerintah Pemerintah telah menerapkan kebijakan tentang Pembatasan Sosial Berskala Besar dengan meliburkan sekolah dan tempat kerja, penutupan obyek-obyek wisata dan tempat hiburan, pembatasan kegiatan keagamaan serta fasilitas umum. Begitu juga kantor-kantor telah dihimbau untuk membuat aturan agar pegawainya bekerja di rumah. Keempat, struktur birokrasi di mana beberapa pihak dalam hal ini adalah pemerintah kabupaten Sidoarjo beserta jajaran dan pihak terkait untuk melakukan pengawasan. Hal ini dikarenakan pengawasan terhadap penerapan protokol kesehatan selama pandemi Covid-19 menjadi hal penting. Perlu dilakukan pengawasan yang ketat terkait dengan penerapan protokol kesehatan terutama $3 \mathrm{M}$ (memakai masker, mencuci tangan dan menjaga jarak).

\section{PENDANAAN}

Publikasi artikel ini menggunakan dana pribadi dari penulis

\section{UCAPAN TERIMA KASIH}

Pertama-tama kami ucapkan terima kasih atas kepada civitas akademika Universitas Muhammadiyah Sidoarjo atas dukungannya sehingga artikel kami dapat di publish di Jurnal Kebijakan dan Manajemen Publik 


\section{REFERENCES}

Anggara, S. (2014). Kebijakan Publik. CV Pustaka Setia.

Hamdi, M. (2014). Kebijakan Publik: Proses, Analisis dan Partisipasi. Ghalia Indonesia.

Masrul, Abdillah, L. A., Tasnim, Simarmata, J., Daud, Sulaiman, O. K., Prianto, C., Iqba, M., Purnomo, A., \& All, E. (2020). Pandemik COVID-19: Persoalan dan Refleksi di Indonesia. Yayasan Kita Menulis.

Miles, M. B., \& Huberman, A. M. (2014). Qualitative Data Analysis, A Methods Sourcebook Edition 3. Sage Publications.

Sinuhaji, J. (2021). Update, Kasus Virus Corona Indonesia per 18 April 2021, Positif Tembus 1,6 Juta, Meninggal 43.424. Pikiran Rakyat@com. https://www.pikiran-rakyat.com/nasional/pr011791680/update-kasus-virus-corona-indonesiaper-18-april-2021-positif-tembus-16-jutameninggal-43424

Solichin, A. W. (2012). Analisis Kebijakan Dari Formulasi ke Penyusunan Model-Model Implementasi Kebijakan Publik. PT Bumi Aksara.

Waseso, H. P., \& Hidayat, M. S. (2016). Mengaplikasikan kurikulum berbasis KKNI pengalaman di prodi PGMI UNSIQ jawa tengah/ Hendri Purbo Waseso, Muhtar Sofwan Hidayat Mengaplikasikan kurikulum berbasis KKNI pengalaman di prodi PGMI UNSIQ jawa tengah/ Hendri Purbo Waseso, Muhtar Sofwan Hiday. Wonosobo: Mangku Bumi.
Conflict of Interest Statement: The authors declare that the research was conducted in the absence of any commercial or financial relationships that could be construed as a potential conflict of interest.

Copyright $(92021$ Hendra Sukmana. This is an open-access article distributed under the terms of the Creative Commons Attribution License (CC BY). The use, distribution or reproduction in other forums is permitted, provided the original author(s) and the copyright owner(s) are credited and that the original publication in this journal is cited, in accordance with accepted academic practice. No use, distribution or reproduc- tion is permitted which does not comply with these terms. 